$\stackrel{N / N}{=}$

Global burnals Inc.

है

\title{
Can the Godelieve Denys-Struyf (GDS) Muscle and Articulation Chains Method Help in the Treatment of Hyperventilation?
}

By Heleno Almeida Júnior, Renata Ungier de Mayor \& Alexandre de Mayor Introduction- Breathing is the most vital function in living beings. When breathing happens in a disordered manner in human beings, that may be the first sign that we are experiencing some dysfunction, whether mechanical, physiological, or psychological (CLIFTONSMITH and ROWLEY, 2011).

One respiratory dysfunction that gets scientific attention due to its complexity is the hyperventilation syndrome (HVS). This syndrome is characterized by a set of somatic symptoms induced by inadequate hyperventilation, which may be reproduced completely or partially, by voluntary hyperventilation (RAPIN et al., 2017). According to Lum (1987), hyperventilation may have symptoms similar to asthma. Therefore, it is necessary to distinguish one of the other, as the treatment of hyperventilation is curable and the procedures for achieving successful treatment differ in approach, mechanisms, and orientation. However, the lack of studies that state treatment efficacy is still a problem (RAPIN et al., 2017; VIDOTTO et al., 2019).

GJMR-K Classification: NLMC Code: WB 460

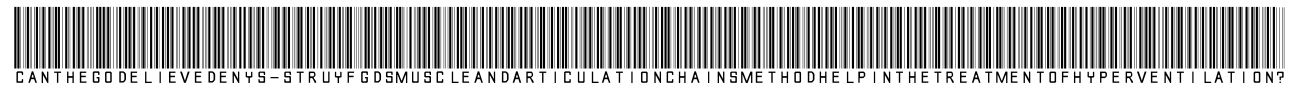

Strictly as per the compliance and regulations of:

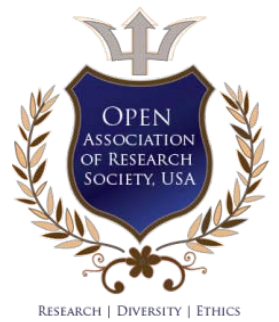

(C) 2019. Heleno Almeida Júnior, Renata Ungier de Mayor \& Alexandre de Mayor. This is a research/review paper, distributed under the terms of the Creative Commons Attribution-Noncommercial 3.0 Unported License http://creative commons.org/licenses/by-nc/3.0/), permitting all non commercial use, distribution, and reproduction inany medium, provided the original work is properly cited. 


\title{
Can the Godelieve Denys-Struyf (GDS) Muscle and Articulation Chains Method Help in the Treatment of Hyperventilation?
}

\author{
Heleno Almeida Júnior ${ }^{\alpha}$, Renata Ungier de Mayor ${ }^{\sigma}$ \& Alexandre de Mayor ${ }^{\rho}$
}

\section{INTRODUCTION}

B reathing is the most vital function in living beings. When breathing happens in a disordered manner in human beings, that may be the first sign that we are experiencing some dysfunction, whether mechanical, physiological, or psychological (CLIFTONSMITH and ROWLEY, 2011).

One respiratory dysfunction that gets scientific attention due to its complexity is the hyperventilation syndrome (HVS). This syndrome is characterized by a set of somatic symptoms induced by inadequate hyperventilation, which may be reproduced completely or partially, by voluntary hyperventilation (RAPIN et al., 2017). According to Lum (1987), hyperventilation may have symptoms similar to asthma. Therefore, it is necessary to distinguish one of the other, as the treatment of hyperventilation is curable and the procedures for achieving successful treatment differ in approach, mechanisms, and orientation. However, the lack of studies that state treatment efficacy is still a problem (RAPIN et al., 2017; VIDOTTO et al., 2019).

HVS may be due to organic or physiological conditions, but its main cause may be related to psychological and behavioral factors (VIDOTTO et al., 2019). Increasingly, in our society, we find case reports of people suffering from anxiety, depression, perfectionism, feelings of inferiority, and others who, usually in times of crisis, may be associated with respiratory disorders such as hyperventilation. Thus, Vidotto et al. (2019) even suggest that it is necessary to create a multidimensional holistic assessment (biochemical, physiological, social, psychological, respiratory symptoms) for the accurate diagnosis of respiratory dysfunction. In this sense, the treatment proposed for HVS should also address the multidimensional holistic aspect, in order to evaluate its effectiveness.

Author $\alpha$ : MSc., Professor at Inspirar College, state of Santa Catarina, Brazil.e-mail: heleno.taichi@gmail.com

Author o: MSc. - Kiné Clínica de Fisioterapia e Centro de Formação, Centre de Formation Professionnel Campignion.

Author p: Expert in this area, Kiné Clínica de Fisioterapia e Centro de Formação, Centre de Formation Professionnel Campignion.
The Muscle and Articulation Chains - G.D.S. Method - (Godelieve Denys-Struyf) is a non-investigated method for HVS that deserves attention. It is a global method of physical therapy and behavioral approach, created by the Belgian physiotherapist Godelieve Denys-Struyf in the 1960s (CAMPIGNION, 2003). More specifically, the work developed by her disciple, the French physical therapist Philippe Campignion, highlights the influences of biomechanical, psychological, behavioral and physiological aspects on breathing, respecting the individuality of each individual (CAMPIGNION, 1998).

Therefore, the present study aims to highlight, based on the available scientific evidence, how G.D.S. can collaborate as a treatment of HVS and bring new perspectives on the subject.

\section{Methods}

It is a systematic literature review. We used the keywords "hyperventilation," "respiratory dysfunction," "exercise," "psychological-behavioral," "GDS method" in Pubmed ${ }^{\circledR}$ and Scielo ${ }^{\circledR}$ databases in Portuguese, French, Spanish, and English, considering articles of the last ten years. Most recent and mentioned review or experimental papers were selected, with at least two of the keywords searched in the present study.

\section{Results}

Except for the keyword "G.D.S method," which only led to two articles, all others presented numerous papers screened according to the methodology adopted in the present study (Table 1). Thus, we highlight the originality of the present study, since, so far, no investigation had been done correlating these keywords or themes. 
Table 1: Top recent and most mentioned articles

\begin{tabular}{|c|c|c|}
\hline Author & Title & Conclusion \\
\hline $\begin{array}{l}\text { Bradley and } \\
\text { Esformes, } \\
\text { (2014) }\end{array}$ & $\begin{array}{l}\text { Breathing pattern disorders and } \\
\text { functional movement }\end{array}$ & $\begin{array}{l}\text { "These results demonstrate the importance of diaphragmatic } \\
\text { breathing on functional movement. Inefficient breathing could } \\
\text { result in muscular imbalance, motor control alterations, and } \\
\text { physiological adaptations that are capable of modifying } \\
\text { movement. These findings provide evidence for improved } \\
\text { breathing evaluations by clinicians." }\end{array}$ \\
\hline $\begin{array}{l}\text { Depiazziand } \\
\text { Everard, } \\
\text { (2016) }\end{array}$ & $\begin{array}{l}\text { Dysfunctional breathing and } \\
\text { reaching one's physiological limit } \\
\text { as causes of exercise-induced } \\
\text { dyspnoea }\end{array}$ & $\begin{array}{l}\text { "Clarity in our approach to dysfunctional breathing is vital if } \\
\text { funding is to be made available for high-quality studies designed } \\
\text { to identify the prevalence and the potential healthcare cost-saving } \\
\text { and improvements in QoL that would follow from accurate } \\
\text { assessment and intervention." }\end{array}$ \\
\hline $\begin{array}{l}\text { Díaz-Arribas } \\
\text { et al., (2014) }\end{array}$ & $\begin{array}{l}\text { Effectiveness of the Godelieve } \\
\text { Denys Struyf (GDS) Method in } \\
\text { People With Low Back Pain: } \\
\text { Cluster Randomized Controlled } \\
\text { Trial }\end{array}$ & $\begin{array}{l}\text { "The improvement in disability was slightly higher with group GDS } \\
\text { sessions than with the program routinely used in clusters within the } \\
\text { SNHS. Adding individualized GDS sessions eliminated this } \\
\text { advantage. Further studies should compare GDS with other types } \\
\text { of exercise." }\end{array}$ \\
\hline $\begin{array}{l}\text { Jones } \\
\text { (2013) }\end{array}$ & $\begin{array}{l}\text { Breathing exercises } \\
\text { dysfunctional } \\
\text { breathing/hyperventilation } \\
\text { syndrome in adults. }\end{array}$ & $\begin{array}{l}\text { "The results of this systematic review are unable to inform clinical } \\
\text { practice, based on the inclusion of only one small, poorly reported } \\
\text { RCT. There is no credible evidence regarding the effectiveness of } \\
\text { breathing exercises for the clinical symptoms of DB/HVS. It is } \\
\text { currently unknown whether these interventions offer any added } \\
\text { value in this patient group or whether specific types of breathing } \\
\text { exercise demonstrate superiority over others. Given that breathing } \\
\text { exercises are frequently used to treat DB/HVS, there is an urgent } \\
\text { need for further well designed clinical trials in this area. Future } \\
\text { trials should conform to the CONSORT statement for standards of } \\
\text { reporting and use appropriate, validated outcome measures. Trial } \\
\text { reports should also ensure full disclosure of data for all important } \\
\text { clinical outcomes." }\end{array}$ \\
\hline $\begin{array}{l}\text { Kim et al., } \\
(2019)\end{array}$ & $\begin{array}{l}\text { Effects of elastic band } \\
\text { resistance exercises with breathi } \\
\text { ng techniques on pulmonary } \\
\text { function in female seniors. }\end{array}$ & $\begin{array}{l}\text { "The results show that resistance accompanied by breathing } \\
\text { techniques positively affects senior respiratory function when an } \\
\text { elastic band is used for exercise." }\end{array}$ \\
\hline $\begin{array}{l}\text { Puppin et al., } \\
\text { (2011) }\end{array}$ & $\begin{array}{l}\text { Stretching in nonspecific chronic } \\
\text { low back pain: a strategy of the } \\
\text { GDS method }\end{array}$ & $\begin{array}{l}\text { "Stretching exercises, proposed by the GDS muscular and } \\
\text { articular chain method, were effective in reducing pain, functional } \\
\text { disability, and increasing overall flexibility, but it did not improve } \\
\text { the ability of the transverse abdomen to contract in patients with } \\
\text { chronic and unspecific low back pain." }\end{array}$ \\
\hline $\begin{array}{l}\text { Rapin et al., } \\
(2017)\end{array}$ & $\begin{array}{l}\text { Which treatments for the } \\
\text { hyperventilation syndrome in } \\
\text { adults? }\end{array}$ & $\begin{array}{l}\text { "In practice, it provides learning about abdominal ventilation and } \\
\text { respiratory rate regulation. Coupled with personalized therapeutic } \\
\text { education, it seems to be the most appropriate technique. Other } \\
\text { clinical studies are needed." }\end{array}$ \\
\hline $\begin{array}{l}\text { Szulczewski, } \\
\text { (2019) }\end{array}$ & $\begin{array}{l}\text { Training of paced breathing at } 0.1 \\
\mathrm{~Hz} \text { improves } \mathrm{CO}_{2} \text { homeostasis } \\
\text { and relaxation during a paced } \\
\text { breathing task }\end{array}$ & $\begin{array}{l}\text { "The obtained results showed that training paced breathing at } 0.1 \\
\mathrm{~Hz} \text { led to decrease in hyperventilation. Furthermore, the present } \\
\text { study suggests that training paced breathing is necessary to make } \\
\text { the task more pleasant and relaxing." }\end{array}$ \\
\hline $\begin{array}{l}\text { Vidotto e } \\
\text { (2019) }\end{array}$ & $\begin{array}{l}\text { Respiratory Dysfunction: What Do } \\
\text { We Know About it? }\end{array}$ & $\begin{array}{l}\text { "Finally, the treatment of patients with RD needs to be further } \\
\text { investigated, not only because of the lack of a diagnostic tool that } \\
\text { allows consistent recruitment of participants but also because of } \\
\text { the scarcity of RCTs that test well-defined protocols for this group } \\
\text { of patients." }\end{array}$ \\
\hline
\end{tabular}




\begin{tabular}{|l|l|l|l|l}
\hline $\begin{array}{l}\text { Zaccaro } \\
\text { al., (2018) et }\end{array}$ & $\begin{array}{l}\text { "Slow breathing techniques act enhancing autonomic, cerebral } \\
\text { and psychological flexibility in a scenario of mutual interactions: } \\
\text { Your Life: A Systematic Review on } \\
\text { Psycho-Physiological Correlates } \\
\text { of Slow Breathing } \\
\text { increased HRV and LF power), CNS activities (increased EEG } \\
\text { alpha power and decreased EEG theta power) related to } \\
\text { emotional control and psychological well-being in healthy } \\
\text { subjects." }\end{array}$ \\
\hline
\end{tabular}

Note: QoL= quality of life; GDS = Godelieve Denys Struyf; SNHS = Spanish National Health Service; DB/HVS = Dysfunctional breathing/hyperventilation syndrome; RCT = randomised controlled trial; CONSORT = Consolidated Standards of Reporting Trials; EEG = Electroencephalography; HRV = Heart Rate Variability; LF = Low Frequency; CNS = Central Nervous System

\section{Discussion}

The biochemical components and physiological effects of the hyperventilation syndrome are well understood by the authors in their articles, even in previous studies such as George's, (1964), Lum's, (1987) and Chaitow's, (2004).

Hyperventilation causes an increase in ventilation rate. The exhalation rate of carbon dioxide $\left(\mathrm{CO}_{2}\right)$ exceeds the accumulated rate in tissues, causing a decrease in $\mathrm{CO}_{2}$ and an increase in body $\mathrm{pH}$, producing respiratory alkalosis (CHAITOW, 2004). According to Chaitow (2004), this induces vasoconstriction, decreasing blood flow and inhibiting hemoglobin transfer (from oxygen to cell tissue due to the Bohr effect), and inevitably muscles end up being affected by fatigue, dysfunction, and trigger points.

On the other hand, some authors show different opinions about the relationship between psychological and behavioral factors and hyperventilation. Lum (1987) addresses the behavioral factors as symptoms caused by hyperventilation, i.e., a somatopsychic pathway. Vidotto et al. (2019) discuss a psychosomatic one, where psychological and behavioral factors would be the main causes of hyperventilation. Regardless of the route, everyone should consider psychosomatic aspects, from biomechanical dysfunction to unstable emotions to resolve hyperventilation. Perhaps this is why some studies such as Jones et al. (2013) did not find lots of clear and positive results about exercise in the treatment of hyperventilation.

According to Rapin et al. (2017), the most appropriate technique apparently would be abdominal ventilation with respiratory rate regulation, combined with an individualized therapeutic education. According to Campignion (1998), however, only abdominal ventilation happens only when the body adopts a resting breath. In this sense, it is paramount to adopt some relaxation or even reprogram the mechanical ventilation at the most active moment as well. There are several breathing techniques and approaches aimed at improving ventilation. In hyperventilation, according to Szulczewski (2019), the slow breathing exercise favors the reduction of the picture. Still, not all people can breathe slowly because of mechanical difficulties, making something that should be pleasurable to accomplish, something unpleasant.

Philippe Campignion has developed his extensive work on the physiology of respiratory mechanics from a range of concepts. Based on Françoise Mézières's maxim, "Breathing is not taught or learned, it is released," as well as Godelieve DenysStruyf's work on muscle and articulation chains. Her view that "each individual adopts a body attitude that is his or her own and derives from his or her psychological and behavioral experience" was the starting point for the study of the relationship between different postures and respiratory biomechanical behavior, taking into account the associated morphological diversity, especially regarding the shape and positioning of the chest. She then established the different respiratory typologies described in her work: chest blocked in inspiratory position, chest with large anteroposterior diameter, paradoxical chest with a small anteroposterior diameter and large lateral diameter, chest expired or chest with small diameter, asthenic chest (CAMPIGNION, 1998). Philippe Campignion uses these concepts for both evaluation and exercise proposal for each typology, respecting the individuality of each patient. The purpose of this approach is to release mechanical barriers, if there is any, and to reprogram the well-coordinated mechanics, thus contributing to proper respiratory physiology.

Biomechanical aspects are also fundamental in his work, as she reports the predispositions in case of the permanence of mechanical barriers and the relationship between the diaphragm and the visceral system (CAMPIGNION, 1998). This information is interesting because gastrointestinal and circulatory dysfunctions and other problems that may arise concomitantly with hyperventilation may be of psychological and behavioral origin, with biomechanical consequences.

This view stimulates future research, as there are still scientific gaps on the subject of hyperventilation, evaluation, and appropriate exercise. In the same way, it is relevant the need for more scientific investigation Philippe Campignion's approach, given the lack of articles on such an important subject. This proposal not only should include research on individual work but also on group work. 
It is necessary to highlight that the comprehension of the human being in its totality may bring answers or solutions to the most diverse disorders. The perspective addressed in the present study is confirmed by what the authors presented here highlighted about hyperventilation. It is increasingly important to conduct studies on hyperventilation that consider the complexity of the human being and the intrinsic and extrinsic influences, both in his or her life as a whole and in the specific moment in which the pathology affects him or her.

\section{Conclusion}

Despite the approach of the Muscle and Articulation Chains - G.D.S. Method in the treatment of HVS seems promising; experimental studies are needed to prove its effectiveness.

\section{References Références Referencias}

1. CliftonSmith T., Rowley J. Breathing pattern disorders and physiotherapy: inspiration for our profession. Physical Therapy Reviews. 2011; 16: 75-83.

2. Bradley $\mathrm{H}$., Esformes J. Breathing pattern disorders and functional movement. Int $\mathrm{J}$ Sports Phys Ther. 2014; 9(1): 28-39.

3. Campignion, P. Aspectos Biomecânicos: cadeiasmusculares e articulares - método G.D.S.: noçõesbásicas / Philippe Campignion; tradução Maria Lucia Campello Hahn. São Paulo: Summus, 2003.

4. Campignion, P. Respir-Ações/Philippe Campignion; tradução Maria Lucia Campello Hahn. São Paulo: Summus, 1998.

5. Chaitow L. Breathing pattern disorders, motor control, and low back pain. Journal of Osteopathic Medicine, 2004; 7(1): 34-41.

6. DepiazziJ., Everard M. L. Dysfunctional breathing and reaching one's physiological limit as causes of exercise-induced dyspnoea. Breathe (Sheff). 2016; 12(2): 120-9.

7. Díaz-Arribas M. J., Kovacs F. M., Royuela A., Fernández-Serrano M., Gutiérrez-Fernández L, etal. Effectiveness of the Godelieve Denys Struyf (GDS) method in people with low back pain: cluster randomized controlled trial. Phys Ther. 2015; 95(3): 319-36.

8. George S. Changes in serum calcium, serum phosphate and red cell phosphate during hyperventilation. New Engl J Med. 1964; 270: 726-728.

9. Jones M., Harvey A., Marston L., O'Connell N.E. Breathing exercises for dysfunctional breathing/ hyperventilation syndrome in adults. Cochrane Database Syst Rev. 2013; 31(5): CD009041.
10. Kim K., Han J. W., Kim Y. M. Effects of elastic band resistance exercises with breathing techniques on pulmonary function in female seniors. J Exerc Rehabil. 2019; 15(3): 419-423.

11. Lum L. Hyperventilation syndromes in medicine and psychiatry. Journal of the Royal Society of Medicine. 1987; 229-231.

12. Puppin M.A.F.L., Marques A. P., Silva A. G., FuturoNeto H. A. Stretching in nonspecific chronic low back pain: a strategy of the GDS method. Fisioterapia e Pesquisa. 2011; 18(2): 116-21.

13. Rapin A., Deslee G., Percebois-Macadre L., Jonvel A. C., Demangeon S., Boyer F. C. Which treatments for the hyperventilation syndrome in adults?. Rev Mal Respir. 2017; 34(2): 93-101.

14. Szulczewski, M. T. Training of paced breathing at $0.1 \mathrm{~Hz}$ improves $\mathrm{CO}_{2}$ homeostasis and relaxation during a paced breathing task. PLoSOne. 2019; 14(6): e0218550.

15. Vidotto L. S., Carvalho C.R.F., Harvey A., Jones M. Disfunção respiratória: o que sabemos?.J Bras Pneumol. 2019; 45(1): e20170347.

16. Zaccaro A., Piarulli A., Laurino M., Garbella E., Menicucci D., Neri B., Gemignani A. How BreathControl Can Change Your Life: A Systematic Review on Psycho-Physiological Correlates of Slow Breathing. Front Hum Neurosci. 2018; 12: 353. 